\title{
Methods for Monitoring the Effects of Grazing Management on Bank Erosion and Channel Morphology, Fever River, Pioneer Farm, Wisconsin, 2004
}

\section{Introduction}

Bank erosion is a natural process that occurs in meandering streams (Leopold and others, 1964); however, in the Midwestern United States, historical and present agricultural activities in uplands, riparian areas, and channels have increased erosion (Waters, 1995; Lyons and others, 2000; Simon and Rinaldi, 2000; and Knox, 2001). Reducing streambank erosion is important because sediment carried by streams has adverse environmental effects; for example, sediment carried by streams is a major source of phosphorus (Waters, 1995). Continuous cattle grazing in riparian areas may increase local erosion processes in a meandering stream by removal or trampling of bank vegetation, which in turn affects channel morphology, water chemistry, and fish and aquaticinsect habitat (Kauffman and Krueger, 1984; Fitch and Adams, 1998). However, studies of livestock exclusion from riparian corridors have shown mixed results in reducing bank erosion (Trimble, 1994; Sarr, 2002). Some

\section{Managed Grazing - Rotational Deferred}

There are many different methods for managing livestock-grazing activities. Rotational grazing or stocking is defined as the practice of allowing livestock to graze in two or more paddocks of a larger pasture with rest periods between grazing periods (Forage and Grazing Terminology Committee, 1991). The nonsystematic rotation of stock with the goal of achieving a specific management objective is defined as deferred grazing. At Pioneer Farm, rotational-deferred grazing meets the goal of returning pastures to environmental conditions appropriate for grazing by moving the herd on the basis of shade, forage needs, and pasture conditions. The length of the grazing period generally is shorter than the rest period. Because of the limited amount of time the cattle spend in an area and the longer rest time allowed for vegetation recovery, negative effects on the streambank are thought to be reduced (Kauffman and Kruger, 1984). studies have shown reduced bank erosion after row-cropped or continuously grazed riparian areas are converted to managed grazing (see inset box) (Lyons and others, 2000; Sovell and others, 2000; and Zaimes and others, 2004).

In May 2002, seven rotational-deferred paddocks were established in a riparian pasture along a 0.8-mile reach, or section, of the Fever River at the University of Wisconsin (UW)Platteville Pioneer Agricultural Stewardship Farm in southwestern Wisconsin (fig. 1). From 1996 to 2002, this pasture had been used for rotational grazing in five paddocks. In 2002, the fences were changed to create the seven present (2004) paddocks. Four cattle crossings were installed by the end of winter 2003 . In 2001, the U.S. Geological Survey (USGS) began monitoring runoff, solids, nutrients, bacteria, and selected pesticides from various upland fields with a variety of best management practices. Some of the sampling locations for this study are noted in figure 1. In June 2004, the USGS, in cooperation with the UW-Platteville

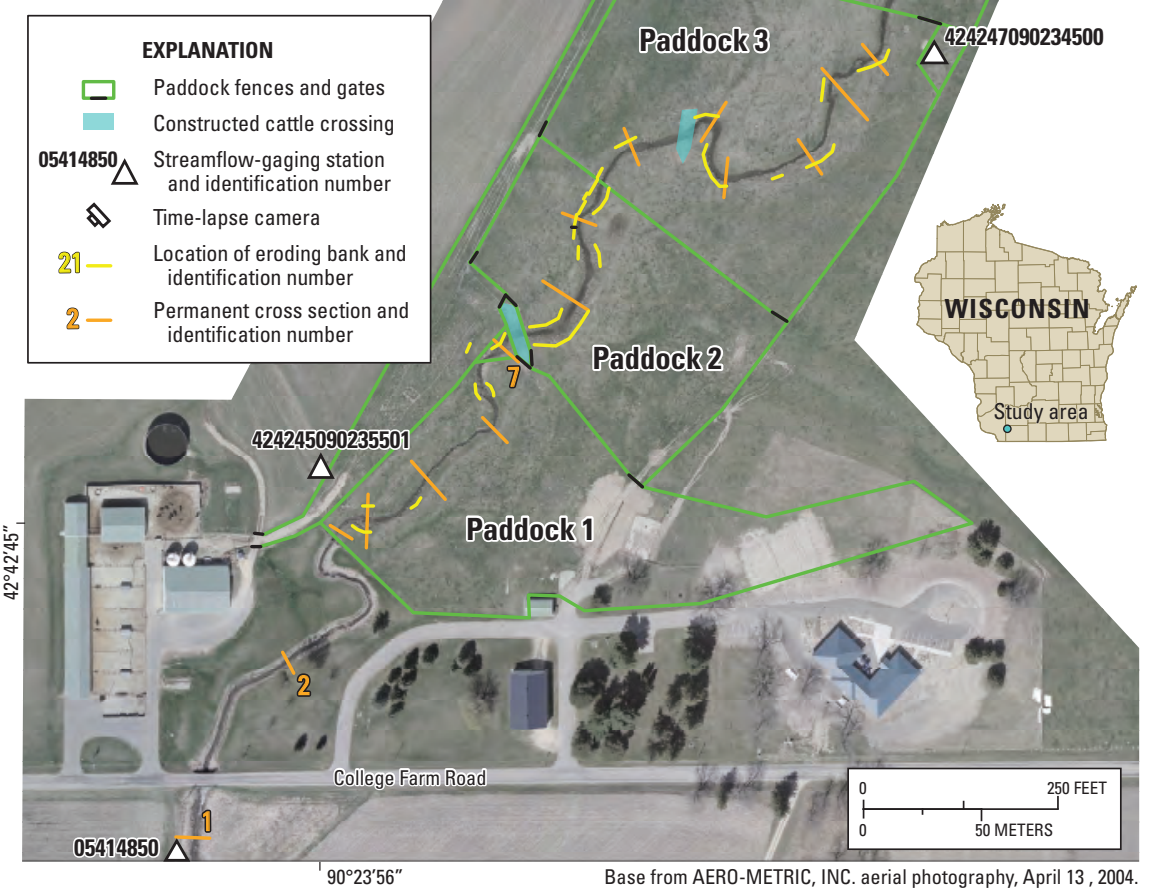

Figure 1. Pioneer Farm beef cattle rotational grazing pasture. The pasture is divided into seven rotational grazing paddocks. Only banks and transects mentioned in this report have been labeled. 
Table 1. Pasture characteristics and monitoring information for rotational-deferred paddocks at Pioneer Farm, Wisconsin, 2004.

[ns, not surveyed]

\begin{tabular}{lccccc}
\hline Section & $\begin{array}{c}\text { Area of } \\
\text { paddock, } \\
\text { in acres }\end{array}$ & $\begin{array}{c}\text { Percent of total } \\
\text { bank length } \\
\text { monitored }\end{array}$ & $\begin{array}{c}\text { Number } \\
\text { of cross } \\
\text { sections }\end{array}$ & $\begin{array}{c}\text { Number of erod- } \\
\text { ing banks/ banks } \\
\text { with erosion pins }\end{array}$ & $\begin{array}{c}\text { Number } \\
\text { of erosion } \\
\text { pins }\end{array}$ \\
\hline Paddock 1 to & ns & ns & 2 & ns/ns & ns \\
College Farm Road & & 16.3 & 5 & $7 / 1$ & 6 \\
Paddock 1 & 5.0 & 57.5 & 2 & $10 / 0$ & 0 \\
Paddock 2 & 2.9 & 23.5 & 6 & $8 / 1$ & 1 \\
Paddock 3 & 4.8 & 31.3 & 3 & $11 / 2$ & 15 \\
Paddock 4 & 3.8 & 17.8 & 6 & $10 / 1$ & 3 \\
Paddock 5 & 4.2 & 33.5 & 5 & $10 / 1$ & 3 \\
Paddock 6 & 4.5 & 46.5 & 6 & $18 / 6$ & 31 \\
Paddock 7 & 4.7 & $\mathbf{2 6 . 7}$ & $\mathbf{3 5}$ & $\mathbf{7 4 / 1 1}$ & $\mathbf{5 9}$ \\
Total & $\mathbf{2 9 . 9}$ & & & & 3 \\
\hline
\end{tabular}

* Two cross sections are outside of the paddocks.

Table 2. Example paddock usage for a grazing season, April 20, 2004, through November 15, 2004, Pioneer Farm, Wisconsin. Fourteen days were not listed because of a gap in the data.

\begin{tabular}{ccccc}
\hline Paddock & $\begin{array}{c}\text { Total number of } \\
\text { days }\end{array}$ & $\begin{array}{c}\text { Number of times } \\
\text { in paddock }\end{array}$ & $\begin{array}{c}\text { Days in paddock } \\
\text { (average) }\end{array}$ & $\begin{array}{c}\text { Rest days } \\
\text { (average) }\end{array}$ \\
\hline 1 and 2 & 35 & 5 & $3-19(7)$ & $8-30(20)$ \\
3 & 21 & 7 & $1-5(3)$ & $3-31(14)$ \\
4 & 15 & 4 & $3-5(4)$ & $13-32(20)$ \\
5 & 13 & 4 & $1-5(3)$ & $3-29(20)$ \\
6 & 13 & 5 & $1-5(3)$ & $2-13(7)$ \\
7 & 10 & 4 & $2-4(3)$ & $13-26(19)$ \\
Average & $\mathbf{1 8}$ & $\mathbf{5}$ & $\mathbf{2 - 7 ( 4 )}$ & $\mathbf{7 - 2 7 ( 1 7 )}$ \\
\hline
\end{tabular}

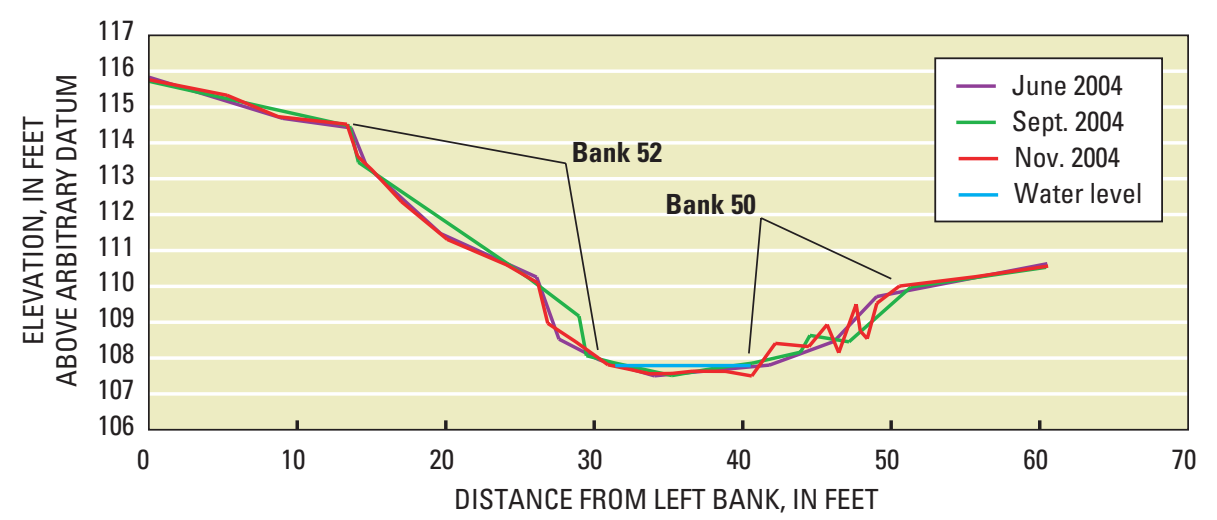

Figure 2. Cross section 33 in paddock 7 showing the development of a cattle crossing at the edge of bank 50 . The steep scratching area of bank 52 is shown in figure 4 .

Pioneer Farm, began monitoring bank and channel changes along the river through this reach. Channel and bank monitoring is designed to continue indefinitely. It is hoped that the methods used during this study can be applied in other grazing locations.

The seven paddocks were established at the farm for a study of the potential advantages of rotational-deferred grazing for the health of cattle and forage, and the water quality of the Fever River (fig. 1). The Fever River is laterally migrating through the pasture; eroding and slumping banks are common and may be developing at an increased rate because of trampling by cattle. The UW-Platteville is interested in long-term monitoring of bank erosion along the reach through the pasture to determine if vegetation and banks are stabilizing as a result of the rotational-deferred practices and constructed cattle crossings.

The major goal of this study is to measure bank erosion, channel shape, location, and stream-substrate changes caused by rotationaldeferred grazing practices. There is no control reach along the Fever River with standard grazing practices; measured decreases in bank erosion and increases in bank stability and vegetation along the reach with rotational-deferred grazing are assumed to be the result of the change in grazing management. The purpose of this Fact Sheet is to describe the ongoing methods used to monitor long-term bank erosion in the pastures. Example data are presented for each method of observing the bank erosion.

\section{Description of Paddocks and Cattle}

The seven paddocks include a total of 30 acres and 4,347 feet (ft) of stream length (table 1). The average paddock area is 4.3 acres. There are three exclosure areas-a small area between paddocks 1 and 2, a larger area between paddock 1 and College Farm Road, and the area around the streamflow-gaging station in paddock 3 (fig. 1). A lane along the west side of the paddocks provides cattle access from the barn to each paddock. Numerous small springs and seeps are in the pasture and along the banks. The pasture is considered to have medium forage quality. Small parts of paddocks 1, 2, 3, and 4 can be mechanically harvested and are occasionally skipped in the grazing sequence to allow the grass to grow longer for harvest. Portions of paddocks 5 and 6 have wetland areas and are grazed more frequently after a period of dry weather. Paddocks 1 and 7 have the only shade trees in the study area, and, consequently, are grazed more heavily during hot weather.

Beef cattle typically are rotated through the paddocks from late April through early November with the timing of rotations based on when the forage conditions are appropriate or the weather is exceedingly hot (Alicia PrillAdams, UW-Platteville Farm, oral commun., 2004). From April 20 to November 15, 2004, the pastures supported a mixed herd of Red and Black Angus and Hereford-Angus cross cattle consisting of 37 cows and heifers, 23 calves, and 1 bull. The age of the cow herd ranged from yearling to 10 years with an average age of 4 years. (Age is important to note as most of these animals were reared in the pasture prior to the crossing and fence installation.) Each year, from September to November, the number of cattle in the pasture decrease substantially as the calves are weaned and sold. The time spent in each paddock by the herd varies according to the shade and forage needs of the cattle, forage condition, and flooding, but typically lasted 2-5 days during the 2004 grazing period (table 2 ). The cattle were in each paddock over the 2004 season from 4 to 7 times. Average rest periods ranged from 7 to 20 days. The cattle 


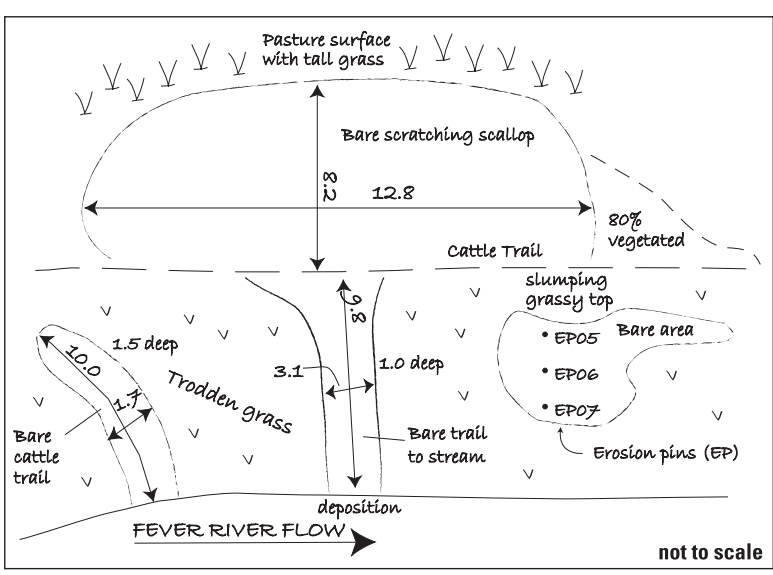

Figure 3. Example sketch of bank measurements and features. Angular view sketches are made of all eroding banks twice a year.

used the constructed crossings but also crossed the channel at various other locations in each paddock. They use the stream as a water source and a place to cool off. A supplemental gravity feeder for the calves was placed in the lane near paddocks 4 and 5 along with the mineral feeder for the cows and calves.

Three types of cattle crossings were constructed at four sites (fig. 1) in the winter and spring of 2003 to allow comparison of cattle use, channel-and bank-stability effects, and cost. The materials used to construct the crossings are gravel and rock, webbing, and recycled tires filled with gravel. Three of the four constructed crossings can be accessed from two paddocks, so that cattle have access to a crossing in all paddocks. The banks are not fenced off from the rest of the paddocks.

\section{Monitoring Bank Erosion and Channel Morphology}

The channel and banks of the Fever River in the seven paddocks were monitored through the use of four methods: channel cross-section surveys, quantitative measurements of eroding banks, erosion pins, and time-lapse photographs. These methods can be used together to form a complete picture of the geomorphic changes in the pasture. Channel cross sections

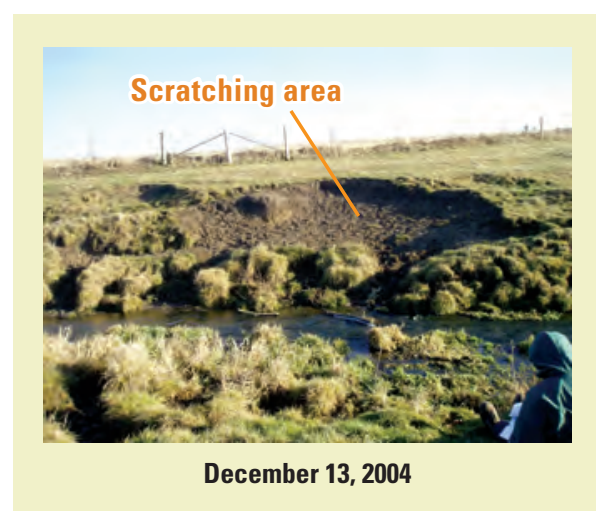

Figure 4. Pronounced scratching area in bank 52 , paddock 7 , with visible cattle paths to the stream. Dimensions are shown in figure 2.

example of the development of a cattle crossing in the Fever River channel since late June 2004 (fig. 2). The irregular surface on bank 50 in the November 2004 survey represents numerous newly developed individual paths that typically make up a stream crossing made by cattle.

Of the approximately 8,700 linear $\mathrm{ft}$ of banks along the Fever River though the pasture, 2,677 $\mathrm{ft}$ are eroding at 73 locations (fig. 1). Additional portions of the banks are eroding, but cover less than 1 contiguous square foot. At each eroding bank, measurements of eroding area (length, width, and depth), notes on connectivity with the stream

are surveyed approximately every 2 months from spring to fall, roughly coinciding with the cattle-grazing schedule and runoff events such as the spring melt (Harrelson and others, 1994). At the time of the cross-section survey, the steel erosion pins were measured and photographs of each bank were retaken from established photo points. Every 6 months, areas of eroding banks are measured. A time-lapse camera was installed in August 2004 and took photos of paddocks 1 through 4 every 8 to 24 hours. The time-lapse photos show pasture conditions and forage length.

Thirty-five channel cross sections (fig. 1, table 1) were established to measure channel movement, incision or aggradation, and bank failures by the methods of Harrelson and others (1994). Two cross sections are in two exclosure areas (cross-sections 2 and 7), and a third cross-section is located south of College Farm Road at the USGS long-term streamflow-gaging station (05414850) (cross-section 1, fig. 1). The cross sections were spaced roughly evenly along the length of the river and represent channel conditions in meander bends and straight stretches. Steel reinforcement bars with numbered plates welded to the top were pounded flush to the ground surface to mark the cross-section endpoints permanently yet prevent cattle injury. Cross-section 33 shows an and causes for erosion, drawings or sketches, and photos were made (fig. 3). Possible causes for erosion include hydraulic or freezing and thawing forces acting against the base or toe of a bank, mass wasting along upper banks on the outside of bends where the stream intersects a terrace, cattle trampling (crossing the stream or walking along the bank), and cattle scratching (fig. 6) on the bank, or a combination of causes. Sketches of the eroding banks included locations of cross sections and erosion pins. A photo point was established for each bank and photos were taken approximately every 2 months. A photograph of bank 52 in December 2004 shows the decreased vegetation and a scratching corner (fig. 4). Photographs of bank 36 show the development of slumping caused by cattle trampling along the top edge of the bank (fig. 5). The photos illustrate how the height of the vegetation along the bank (related to the length of the rest period) may affect interpretations of bank stability.

Eroding-terrace cuts are often enhanced by repeated cattle scratching (fig. 6). The bare spot may be formed initially by hydraulic erosion which can lead to mass wasting at the outsides of bends, or cow trampling. The bare area can then be expanded by scratching. The areas used for scratching typically have a scallop shape,

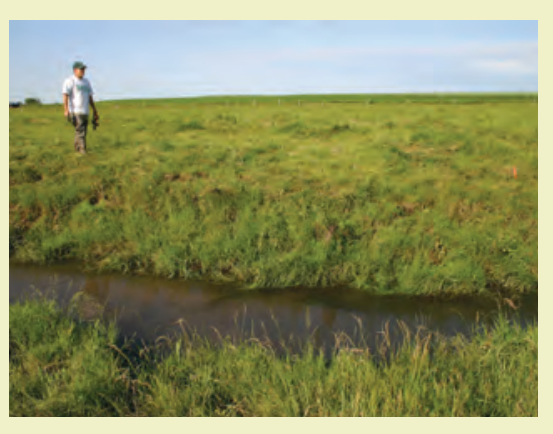

June 23, 2004

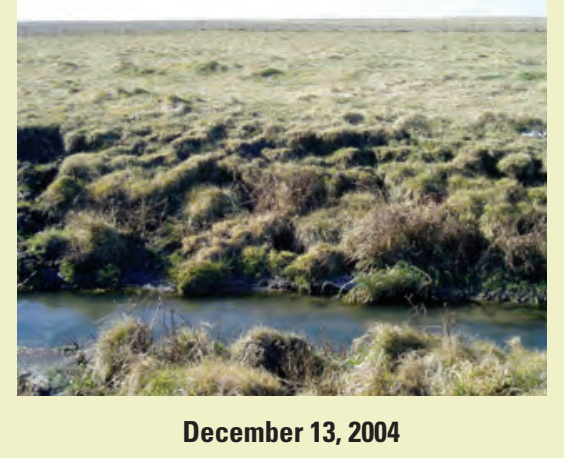

December 13, 2004

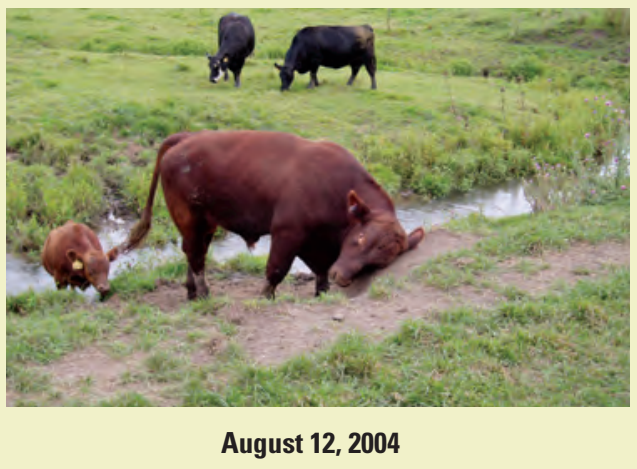

Figure 5. Development of bank slumps from cattle trampling, bank 36, paddock 6 . (Photo at left taken by Randy Mentz.)
Figure 6. Bull scratching on bank 52, paddock 7 . A calf is using a trail leading from the stream to the scratching area. Bank 50 is in the background. 
formed by repeated head movement and hoof scraping (fig. 3). Most, but not all, scratching areas have a direct hydraulic effect on the channel because cattle paths connect the scratching areas to the stream at a non-constructed cattle crossing. Eroding areas enhanced by scratching are recorded in the bank-measurement notes.

Steel erosion pins were set in 12 eroding banks in vertical arrays of two or three pins inserted parallel to the water surface with a known amount of pin left exposed. Each 1/4inch-diameter pin is $2 \mathrm{ft}$ long. The original design included installation of 150 pins; only 59 were installed because only a limited number of locations were available where pins would not potentially injure cattle. Pins were installed only in locations where the bank appeared to be eroding exclusively due to fluvial processes. Two pins were set when the bank was too low to accommodate a three-pin array. The array of three erosion pins was designed to facilitate the monitoring of mass wasting at the top of the banks, shortterm deposition at the water level, and overall erosion as the bank recedes. The typical failure mechanism for the banks is rotational block failure (fig. 7, bank 21). After the block failure at bank 21 that occurred between June 24, 2004, and September 17, 2004, the top erosion pin (EP-19) was ripped out and found in the stream in the remaining clump of slumped vegetation and roots. Depending on the amount of rotation and bank angle, sometimes the failed block covers the bottom erosion pin.

\section{Future Plans for Monitoring Activities}

Channel and bank monitoring is planned to continue indefinitely. Documentation of cattle usage and of changes in hydrologic conditions over time is important to determine how rotational-deferred grazing and constructed channel crossings affect bank and channel conditions. It also is important to document changes in herd composition as well as in stocking rates. When the study began, the cattle herd consisted of two breeds: Hereford-

Angus cross and purebred Angus. For the 2005 grazing season, farm managers have decided to limit the herd to approximately 30 Angus cows. The reduction in herd size will increase forage density and reduce bank trampling. The elimination of older cattle and introduction of younger cattle could affect how the cattle use the crossings and could also affect their grazing patterns. These changes may become apparent through long-term monitoring. Another study at Pioneer Farm is examining forage quality and species and how they are affected by rotational-deferred grazing. Also, alternative water sources and scratching posts are being discussed as variables that could be introduced to the study paddocks to help relieve the cattleuse pressure on the banks. In 2005, Pioneer Farm personnel began to examine how the cattle use the riparian pasture. The additional data on cattle behavior (for example, grazing, scratching, or crossing the stream) may provide insight into how the cattle are affecting the stream channel and banks.

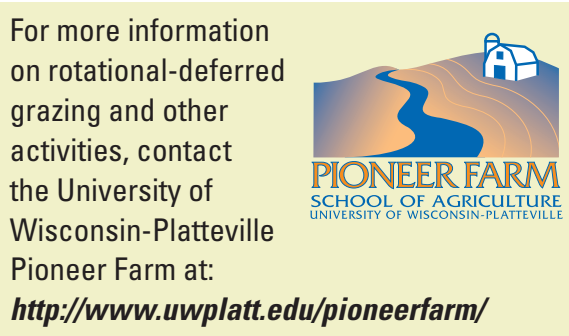

\section{References}

Fitch, L., and Adams, B.W., 1998, Can cows and fish co-exist?: Canadian Journal of Plant Science, v. 78, p. 191-198.

Forage and Grazing Terminology Committee, 1991, Terminology for grazing land and grazing animals: Blacksburg, Vir., Pocahontas Press.

Harrelson, C.C., Rawlins, C.L., and Potyondy, J.P., 1994, Stream channel reference sites-An illustrated guide to field technique: U.S. Department of Agriculture, Forest Service, Rocky Mountain Forest and Range Experiment Station General Technical Report RM-245, 61 p.

Kauffman, J.B., and Krueger, W.C., 1984, Livestock impacts on riparian ecosystems and streamside management implications-a review: Journal of Range Management, v. 37, p. 430-438.
Knox, J.C., 2001, Agricultural influence on landscape sensitivity in the Upper Mississippi River Valley: Catena, v. 42, p. 193-224.

Leopold, L.B., Wolman, M.G., and Miller, J.P., 1964 Fluvial processes in geomorphology: New York, Dover Publications, p. 198-332.

Lyons, J., Trimble, S.W., and Paine, L.K., 2000, Grass versus trees-Managing riparian areas to benefit streams of central North America: Journal of the American Water Resources Association, v. 36, no. 4, p. 919-930.

Sarr, D.A., 2002, Riparian livestock exclosure research in the western United States-A critique and some recommendations: Environmental Management, v. 30, no. 4, p. 516-526.

Simon, A., and Rinaldi, M., 2000, Channel instability in the loess area of the Midwestern United States: Journal of the American Water Resources Association, v. 36, no. 1, p. 133-150.

Sovell, L.A., Vondracek, B., Frost, J.A., and Mumford, K.G., 2000, Impacts of rotational grazing and riparian buffers on physiochemical and biological characteristics of southeastern Minnesota, USA, streams: Environmental Management, v. 26, no. 6, p. 629-641.

Trimble, S.W., 1994, Erosional effects of cattle on streambanks in Tennessee, U.S.A.: Earth Surface Processes and Landforms, v. 19, p. 451-464.

Waters, T.F., 1995, Sediment in streams-sources, biological effects, and control: American Fisheries Society Monograph 7, Bethesda, Maryland, 251 p.

Zaimes, G.N., Schultz, R.C., Isenhart, T.M., Mickelson, S.K., Kovar, J.L., Russell, J.R., Powers, W.P., 2004, Impacts of different land-use practices on stream bank erosion: American Water Resources Association 2004 Summer Specialty Conference Proceedings, June 28-30, 2004, Olympic Valley, California, CD-ROM.

\section{Acknowledgments}

Assistance with field monitoring and cattle movements from Randy Mentz, Alicia PrillAdams, Dennis Busch, and Thomas Hunt, all of Pioneer Farm, UW-Platteville, Wisconsin is greatly appreciated. David Owens, Todd Stuntebeck, and Matt Komiskey (USGS, Middleton, Wisconsin) also helped with monitoring and equipment design.

For information on this study or on other USGS programs in Wisconsin, contact:

Director

USGS Wisconsin Water Science Center

8505 Research Way

Middleton, WI 53562

(608) 828-9901

http://wi.water.usgs.gov/

Authors: Marie C. Peppler and Faith A. Fitzpatrick 